\title{
Physiologic Specialization of Puccinia triticina on Wheat in the United States in 2012
}

J. A Kolmer and M. E. Hughes, United States Department of Agriculture-Agricultural Research Service Cereal Disease Laboratory, St. Paul, MN 55108

\begin{abstract}
Kolmer, J. A., and Hughes, M. E. 2014. Physiologic specialization of Puccinia triticina on wheat in the United States in 2012. Plant Dis. 98:11451150 .

Collections of Puccinia triticina were obtained from rust-infected leaves provided by cooperators throughout the United States and from wheat fields and breeding plots by United States Department of Agriculture-Agricultural Research Service personnel and cooperators in the Great Plains, Ohio River Valley, southeastern states, and Washington State and Idaho in order to determine the virulence of the wheat leaf rust population in 2012. Single uredinial isolates (501 in total) were derived from the collections and tested for virulence phenotype on 20 lines of 'Thatcher' wheat that are near-isogenic for leaf rust resistance genes. In 2012, 74 virulence phenotypes were described in the United States. Virulence phenotypes TNBGJ, TCRKG, and MBTNB were the

three most common phenotypes. Phenotype TNBGJ is virulent to Lr39/41 and was widely distributed throughout the hard red winter wheat region of the Great Plains. Phenotype TCRKG is virulent to Lr11, Lr18, and $\operatorname{Lr} 26$ and was found mostly in the soft red winter wheat region in the eastern United States. Phenotype MBTNB is virulent to LrI1 and was also found mostly in the soft red winter wheat region. The frequency of isolates with virulence to $L r 39 / 41$, which is present in many hard red winter wheat cultivars in the Great Plains region, continued to increase. Isolates with virulence to $L r 21$, which is present in many hard red spring wheat cultivars, also continued to increase in frequency in the northern Great Plains region.
\end{abstract}

Leaf rust, caused by Puccinia triticina Erikss., is a common disease of wheat (Triticum aestivum L.) in the United States (5) and worldwide (25). The leaf rust fungus $P$. triticina is well adapted to regions where wheat is grown in warm continental climates such as North America, Russia (20), and Central Asia (21), and also in humid coastal regions such as Brazil, Uruguay (2), and Turkey (14). In the United States, leaf rust infections can overwinter in the southern Great Plains region of Texas, Oklahoma, and Kansas and also in the southeastern region from Louisiana to Virginia (24). As the winter wheat crop matures in spring, urediniospores are produced on infected winter wheat plants and are carried by the southerly winds to the wheat-producing regions in the Northern Great Plains, Ohio Valley, and northeastern states. Leaf rust can survive and spread easily in the United States because many of the most commonly grown hard red and soft red winter wheat cultivars are susceptible.

The hard red winter wheat cultivars grown in the Great Plains region and the soft red winter wheat cultivars grown in the southeastern and eastern United States have leaf rust resistance genes that are effective in seedlings and that condition resistance to specific races or virulence phenotypes of leaf rust. In recent years, hard red winter wheat cultivars with genes $\operatorname{Lr} 17, \operatorname{Lr} 24$, and $L r 39 / 41$ have been widely grown in the southern Great Plains. Virulence phenotypes with virulence to these genes have increased rapidly in response to the presence of the leaf rust resistant wheat cultivars $(10,11)$, rendering the resistance genes ineffective within a few

Corresponding author: J. A. Kolmer, E-mail: Jim.Kolmer@ars.usda.gov

Accepted for publication 26 February 2014.

http://dx.doi.org/10.1094/PDIS-12-13-1267-SR

This article is in the public domain and not copyrightable. It may be freely reprinted with customary crediting of the source. The American Phytopathological Society, 2014. years of their use. A few notable cultivars included 'Jagger' with Lr17, 'Jagalene' with Lr24, and 'Overley' with Lr39/41 (J. Kolmer, unpublished data). All of these cultivars were associated with the increase of virulent phenotypes of $P$. triticina. Similarly, the soft red winter wheat cultivars also have seedling resistance genes that have proven to be highly vulnerable to selection of virulent phenotypes. Genes $\operatorname{Lr} 9, \operatorname{Lr} 11, \operatorname{Lr} 18$, and $\operatorname{Lr} 26$ have been postulated (9) to be present in soft red winter wheat cultivars, and virulence phenotypes with virulence to these genes are common. In the northern Great Plains, hard red spring wheat cultivars such as 'Faller' and 'Prosper' with $\operatorname{Lr} 21$ were resistant until phenotypes with virulence to $L r 21$ were first found in Minnesota and North Dakota (6). Now, cultivars with only $\operatorname{Lr} 21$ for leaf rust resistance are among the most susceptible spring wheat cultivars.

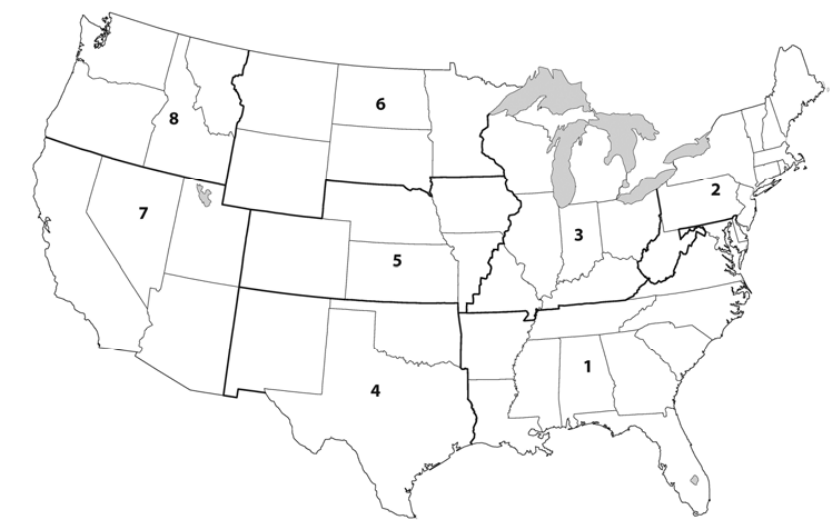

Fig. 1. Agroecological areas for Puccinia triticina in the United States. Area 1, mainly southern-adapted soft red winter wheat; areas 2 and 3 , mostly northernadapted soft red and soft white winter wheat; area 4, mixed wheat types but primarily hard red winter; area 5 , hard red winter wheat; area 6 , mixed wheat types but primarily hard red spring and durum; area 7, spring wheat planted in late fall; and area 8 , mixed wheat types but primarily soft white winter. 
Yield losses due to leaf rust have been heaviest in the winter wheat region from Pennsylvania to Kansas and Oklahoma $(3,24)$. Years with the heaviest yield losses often had temperature and moisture conditions that also favored wheat yields. In the last 20 years, leaf rust has caused an average loss of nearly $3 \%$ in Kansas, (1) although annual losses can be much higher, as in 2007, when leaf rust caused a $14 \%$ loss. In heavy epidemic years, losses due to leaf rust in plots of spring wheat cultivars were 5 to $40 \%$, depending on the resistance of the cultivar (J. Kolmer, unpublished data).

The United States Department of Agriculture-Agricultural Research Service (USDA-ARS) Cereal Disease Laboratory has conducted virulence surveys of the wheat leaf rust fungus since 1978 (17) to detect new virulence phenotypes and to monitor shifts of virulence phenotypes in the major-wheat growing regions of the United States. Earlier surveys of leaf rust virulence that started in 1926 were conducted by the USDA-ARS in Kansas (4) and Indiana (18). Similar surveys have been done in Canada since 1931 (19). In the United States (15) and Canada (8), data from leaf rust surveys have been used to characterize virulence dynamics and phenotypic diversity within and between wheat-growing regions. The objectives of this study were to characterize the virulence of $P$. triticina populations in the United States in 2012 with the North American wheat leaf rust differentials and to compare these results with those of previous surveys.

\section{Materials and Methods}

Leaf rust occurrence and isolate collections. In 2012, USDAARS personnel and cooperators in the United States made a total of 259 uredinial collections of leaf rust from wheat plots and fields in surveys of the Great Plains, Ohio River Valley, and southeastern states. Field surveys of wheat were made by USDA-ARS personnel in central and northern Texas (late March); Oklahoma, Kansas, and western Missouri (late May); north-central Kansas, Nebraska, western Iowa, South Dakota, and southern Minnesota (mid-June); Ohio Valley (mid-June); Washington and Idaho (early August); and Minnesota, North Dakota, South Dakota, and Wisconsin (early July and again in late July). Additional collections were made in wheat breeding nurseries, trap plots, and demonstration plots along the route. Nurseries typically contain a wide array of regional cultivars and breeding lines with various combinations of leaf rust resistance genes. Trap plots usually contain older, leaf-rust-susceptible wheat cultivars that are no longer prominent in commercial production. A collection consisted of one to several leaves with $P$. triticina uredinia from a single plant or cultivar. The leaves were air dried at room temperature and stored at $4^{\circ} \mathrm{C}$ until spores were collected for inoculation and increase. Collections from inoculated nurseries were not included in the study.

Identification of virulence phenotypes. Urediniospores from each collection were used to inoculate 7-day-old seedlings of 'Lit-

Table 1. Number $(N)$ and frequency $(\%)$ of virulence phenotypes of Puccinia triticina in the United States in 2012 identified by virulence to 20 lines of wheat with single genes for leaf rust resistance ${ }^{\mathrm{a}}$

\begin{tabular}{|c|c|c|c|c|c|c|c|c|c|c|c|c|c|c|c|c|c|}
\hline \multirow[b]{2}{*}{ Phenotype } & \multirow[b]{2}{*}{ Virulences } & \multicolumn{2}{|c|}{ Area $1^{b}$} & \multicolumn{2}{|c|}{ Area $2^{c}$} & \multicolumn{2}{|c|}{ Area 3 } & \multicolumn{2}{|c|}{ Area $4^{e}$} & \multicolumn{2}{|c|}{ Area $5^{f}$} & \multicolumn{2}{|c|}{ Area 6 ${ }^{\mathrm{g}}$} & \multicolumn{2}{|c|}{ Area $8^{\text {h }}$} & \multicolumn{2}{|c|}{ Total } \\
\hline & & $N$ & $\%$ & $N$ & $\%$ & $N$ & $\%$ & $N$ & $\%$ & $N$ & $\%$ & $N$ & $\%$ & $N$ & $\%$ & $N$ & $\%$ \\
\hline FCPSB & $2 \mathrm{c}, 3,26,3 \mathrm{ka}, 17,30, \mathrm{~B}, 10,14 \mathrm{a}$ & 0 & 0 & 0 & 0 & 1 & 1.4 & 0 & 0 & 0 & 0 & 0 & 0 & 0 & 0 & 1 & 0.2 \\
\hline LCDNB & $1,26,17, \mathrm{~B}, 14 \mathrm{a}$ & 0 & 0 & 2 & 12.5 & 0 & 0 & 0 & 0 & 0 & 0 & 0 & 0 & 0 & 0 & 2 & 0.4 \\
\hline MBBJG & $1,3,10,14 a, 28$ & 0 & 0 & 0 & 0 & 0 & 0 & 0 & 0 & 0 & 0 & 0 & 0 & 7 & 21.9 & 7 & 1.4 \\
\hline MBBSG & $1,3, \mathrm{~B}, 10,14 \mathrm{a}, 28$ & 0 & 0 & 0 & 0 & 0 & 0 & 0 & 0 & 0 & 0 & 0 & 0 & 1 & 3.1 & 1 & 0.2 \\
\hline MBDRG & $1,3,17, \mathrm{~B}, 10,18,28$ & 0 & 0 & 0 & 0 & 0 & 0 & 0 & 0 & 0 & 0 & 0 & 0 & 1 & 3.1 & 1 & 0.2 \\
\hline MBDSB & $1,3,17, \mathrm{~B}, 10,14 \mathrm{a}$ & 0 & 0 & 0 & 0 & 1 & 1.4 & 0 & 0 & 1 & 1.1 & 1 & 1.5 & 3 & 9.4 & 6 & 1.2 \\
\hline MBDSD & $1,3,17, \mathrm{~B}, 10,14 \mathrm{a}, 39 / 41$ & 0 & 0 & 0 & 0 & 1 & 1.4 & 7 & 6.2 & 10 & 10.5 & 6 & 8.8 & 0 & 0 & 24 & 4.8 \\
\hline MBGJG & $1,3,11,10,14 a, 28$ & 0 & 0 & 0 & 0 & 0 & 0 & 0 & 0 & 0 & 0 & 0 & 0 & 1 & 3.1 & 1 & 0.2 \\
\hline MBNSB & 1,3,3ka,17,B,10,14a & 0 & 0 & 0 & 0 & 0 & 0 & 0 & 0 & 0 & 0 & 0 & 0 & 1 & 3.1 & 1 & 0.2 \\
\hline MBPSB & $1,3,3 \mathrm{ka}, 17,30, \mathrm{~B}, 10,14 \mathrm{a}$ & 0 & 0 & 0 & 0 & 1 & 1.4 & 0 & 0 & 1 & 1.1 & 4 & 5.9 & 0 & 0 & 6 & 1.2 \\
\hline MBTNB & $1,3,3 \mathrm{ka}, 11,17,30, \mathrm{~B}, 14 \mathrm{a}$ & 19 & 18.4 & 1 & 6.3 & 25 & 33.8 & 1 & 0.9 & 3 & 3.2 & 0 & 0 & 0 & 0 & 49 & 9.8 \\
\hline MCBJG & $1,3,26,10,14 a, 28$ & 0 & 0 & 0 & 0 & 0 & 0 & 0 & 0 & 0 & 0 & 0 & 0 & 3 & 9.4 & 3 & 0.6 \\
\hline MCBSG & $1,3,26, \mathrm{~B}, 10,14 \mathrm{a}, 28$ & 0 & 0 & 0 & 0 & 0 & 0 & 0 & 0 & 0 & 0 & 0 & 0 & 1 & 3.1 & 1 & 0.2 \\
\hline MCDSB & $1,3,26,17, \mathrm{~B}, 10,14 \mathrm{a}$ & 0 & 0 & 0 & 0 & 1 & 1.4 & 3 & 2.7 & 0 & 0 & 0 & 0 & 3 & 9.4 & 7 & 1.4 \\
\hline MCDSD & $1,3,26,17, \mathrm{~B}, 10,14 \mathrm{a}, 39 / 41$ & 0 & 0 & 0 & 0 & 0 & 0 & 2 & 1.8 & 0 & 0 & 0 & 0 & 0 & 0 & 2 & 0.4 \\
\hline MCGJG & $1,3,26,11,10,14 a, 28$ & 0 & 0 & 2 & 12.5 & 1 & 1.4 & 0 & 0 & 0 & 0 & 0 & 0 & 1 & 3.1 & 4 & 0.8 \\
\hline MCNSB & $1,3,26,3 \mathrm{ka}, 17, \mathrm{~B}, 10,14 \mathrm{a}$ & 0 & 0 & 0 & 0 & 0 & 0 & 1 & 0.9 & 0 & 0 & 0 & 0 & 1 & 3.1 & 2 & 0.4 \\
\hline MCQHG & $1,3,26,3 \mathrm{ka}, 11,10,18,28$ & 0 & 0 & 1 & 6.3 & 0 & 0 & 0 & 0 & 0 & 0 & 0 & 0 & 0 & 0 & 1 & 0.2 \\
\hline MCRJG & $1,3,26,3 \mathrm{ka}, 11,30,10,14 \mathrm{a}, 28$ & 2 & 1.9 & 0 & 0 & 0 & 0 & 0 & 0 & 0 & 0 & 0 & 0 & 0 & 0 & 2 & 0.4 \\
\hline MCTNB & $1,3,26,3 \mathrm{ka}, 11,17,30, \mathrm{~B}, 14 \mathrm{a}$ & 14 & 13.6 & 2 & 12.5 & 4 & 5.4 & 0 & 0 & 3 & 3.2 & 1 & 1.5 & 0 & 0 & 24 & 4.8 \\
\hline MCTNG & 1,3,26,3ka,11,17,30,B,14a,28 & 0 & 0 & 0 & 0 & 0 & 0 & 0 & 0 & 0 & 0 & 1 & 1.5 & 0 & 0 & 1 & 0.2 \\
\hline MCTQB & $1,3,26,3 \mathrm{ka}, 11,17,30, \mathrm{~B}, 10$ & 3 & 2.9 & 0 & 0 & 0 & 0 & 0 & 0 & 0 & 0 & 0 & 0 & 0 & 0 & 3 & 0.6 \\
\hline MCTSB & $1,3,26,3 \mathrm{ka}, 11,17,30, \mathrm{~B}, 10,14 \mathrm{a}$ & 2 & 1.9 & 0 & 0 & 0 & 0 & 0 & 0 & 0 & 0 & 0 & 0 & 0 & 0 & 2 & 0.4 \\
\hline MDDSB & $1,3,24,17, \mathrm{~B}, 10,14 \mathrm{a}$ & 0 & 0 & 0 & 0 & 0 & 0 & 3 & 2.7 & 1 & 1.1 & 0 & 0 & 0 & 0 & 4 & 0.8 \\
\hline MDNSB & $1,3,24,3 \mathrm{ka}, 17, \mathrm{~B}, 10,14 \mathrm{a}$ & 0 & 0 & 0 & 0 & 0 & 0 & 2 & 1.8 & 0 & 0 & 0 & 0 & 0 & 0 & 2 & 0.4 \\
\hline MDPSB & $1,3,24,3 \mathrm{ka}, 17,30, \mathrm{~B}, 10,14 \mathrm{a}$ & 0 & 0 & 0 & 0 & 1 & 1.4 & 0 & 0 & 2 & 2.1 & 1 & 1.5 & 0 & 0 & 4 & 0.8 \\
\hline MFBSB & $1,3,24,26, \mathrm{~B}, 10,14 \mathrm{a}$ & 0 & 0 & 0 & 0 & 1 & 1.4 & 1 & 0.9 & 0 & 0 & 0 & 0 & 0 & 0 & 2 & 0.4 \\
\hline MFDSB & $1,3,24,26,17, \mathrm{~B}, 10,14 \mathrm{a}$ & 0 & 0 & 0 & 0 & 1 & 1.4 & 5 & 4.4 & 1 & 1.1 & 0 & 0 & 0 & 0 & 7 & 1.4 \\
\hline MFGJG & $1,3,24,26,11,10,14 \mathrm{a}, 28$ & 3 & 2.9 & 0 & 0 & 0 & 0 & 0 & 0 & 0 & 0 & 0 & 0 & 0 & 0 & 3 & 0.6 \\
\hline MFNSB & 1,3,24,26,3ka,17,B,10,14a & 2 & 1.9 & 0 & 0 & 2 & 2.7 & 5 & 4.4 & 1 & 1.1 & 0 & 0 & 1 & 3.1 & 11 & 2.2 \\
\hline MFPSB & $1,3,24,26,3 \mathrm{ka}, 17,30, \mathrm{~B}, 10,14 \mathrm{a}$ & 2 & 1.9 & 0 & 0 & 2 & 2.7 & 3 & 2.7 & 6 & 6.3 & 3 & 4.4 & 0 & 0 & 16 & 3.2 \\
\hline MHTSB & $1,3,16,26,3 \mathrm{ka}, 11,17,30, \mathrm{~B}, 10,14 \mathrm{a}$ & 0 & 0 & 0 & 0 & 2 & 2.7 & 0 & 0 & 0 & 0 & 0 & 0 & 0 & 0 & 2 & 0.4 \\
\hline MKDSB & $1,3,16,24,26,17, \mathrm{~B}, 10,14 \mathrm{a}$ & 0 & 0 & 0 & 0 & 0 & 0 & 2 & 1.8 & 0 & 0 & 0 & 0 & 0 & 0 & 2 & 0.4 \\
\hline
\end{tabular}

\footnotetext{
${ }^{a}$ Lines tested were Thatcher lines with genes Lr1, Lr2a, Lr2c, Lr3a, Lr9, Lr16, Lr24, Lr26, Lr3ka, Lr11, Lr17, Lr30, LrB, Lr10, Lr14a, Lr18, Lr21, Lr28, Lr39/Lr41, and Lr42.

${ }^{\mathrm{b}}$ States of Alabama, Arkansas, Georgia, Louisiana, Mississippi, North Carolina, and Virginia.

${ }^{c}$ State of New York.

d States of Illinois, Indiana, eastern Missouri, Ohio, and Wisconsin.

${ }^{\mathrm{e}}$ States of Oklahoma and Texas.

${ }^{\mathrm{f}}$ States of Kansas, western Missouri, and Nebraska.

g States of Minnesota, North Dakota, and South Dakota.

${ }^{\mathrm{h}}$ States of Montana, Washington, and Idaho.
} 
tle Club' wheat that had been treated with a maleic hydrazide solution of approximately $0.01 \mathrm{~g}$ (dissolved in $30 \mathrm{ml}$ of $\mathrm{H}_{2} \mathrm{O}$ ) per pot to enhance spore production. Each pot of 10 to 20 seedlings was sprayed with $0.25 \mathrm{ml}$ of a suspension of spores in Soltrol 170 (Phillips Petroleum) mineral oil. After drying for $1 \mathrm{~h}$, inoculated plants were placed in a dew chamber overnight at $18^{\circ} \mathrm{C}$. The plants were then placed in individual plexiglass isolation chambers in a greenhouse where temperatures varied between 18 and $28^{\circ} \mathrm{C}$ daily, with $16 \mathrm{~h}$ of supplemental greenhouse lighting. After 12 to 15 days, two to three seedlings were saved per collection, each with the primary leaf trimmed to isolate a single uredinium. A cyclone spore collector was used 6 to 9 days later to collect urediniospores separately from two to three single uredinia per collection. The isolates were increased through one uredinial generation on seedlings of Little Club before inoculating differential lines. In all, 2 to $3 \mathrm{mg}$ of urediniospores of the single-uredinial isolates were mixed with $0.25 \mathrm{ml}$ of oil and directly inoculated by atomization onto 7to 8-day-old plants of the differential host series (five to seven plants per line) of near-isogenic lines of 'Thatcher' wheat with single resistance genes $\operatorname{Lr} 1, \operatorname{Lr} 2 a, \operatorname{Lr} 2 c, \operatorname{Lr} 3, \operatorname{Lr} 3 k a, \operatorname{Lr} 9, \operatorname{Lr} 10$, Lr11, Lr14a, Lr16, Lr17, Lr18, Lr21, Lr24, Lr26, Lr28, Lr30, $L r 39 / 41, L r 42$, and $L r B$. A winter wheat line with $L r 42$ was used in the surveys from 2004 to 2007; however, this line was dropped because it was later determined to also have $\operatorname{Lr} 24$, which greatly limited the effectiveness of this line as a differential.
Sets of differential lines were grown in the greenhouse and evaluated for rust infection type (IT) from April to June and from September through the end of January. Natural daylight was supplemented with high-pressure sodium lamps from 0800 to $2400 \mathrm{~h}$. After 10 to 12 days, ITs were recorded as either high (IT 3 to 4 ) or low (IT 0 to $2^{+}$), as previously described (12). A five-letter code based on the original code proposed for $P$. triticina (11) described the low or high ITs of each isolate to the 20 differential lines. Each letter corresponds to the ITs of four differentials. The Thatcher lines with genes $L r 1, L r 2 a, L r 2 c$, and $L r 3$ were the four lines in the first set of differentials; lines with genes $L r 9, L r 16, L r 24$, and $L r 26$ were the second set of differentials; lines with genes $L r 3 k a, L r 11, L r 17$, and $L r 30$ were the third set of differentials; lines with genes $\operatorname{LrB}, \operatorname{LrlO}$, $L r 14 a$, and $\operatorname{Lr} 18$ were the fourth set of differentials; and lines with genes $L r 21, L r 28, L r 39 / 41$, and $L r 42$ were the fifth set of differentials. Sets 1 to 3 are the same as described previously (16). The same first four sets of differentials have been used in $P$. triticina surveys in Canada (7). The fifth set of differentials was added for the first time in U.S. surveys in 2004, because $L r 21$ is present in spring wheat cultivars, $L r 39 / 41$ is present in winter wheat cultivars, and $L r 28$ differentiates $P$. triticina virulence phenotypes. Near-isogenic Thatcher lines with $L r 39 / 41$ and $L r 42$ were used for the first time in 2012.

Phenotype and virulence frequencies were determined for collections from eight agroecological geographic areas, as shown and described in Figure 1. Collections were not obtained from areas 7

Table 1. (continued from preceding page)

\begin{tabular}{|c|c|c|c|c|c|c|c|c|c|c|c|c|c|c|c|c|c|}
\hline \multirow[b]{2}{*}{ Phenotype } & \multirow[b]{2}{*}{ Virulences } & \multicolumn{2}{|c|}{ Area $\mathbf{1}^{\mathrm{b}}$} & \multicolumn{2}{|c|}{ Area $2^{c}$} & \multicolumn{2}{|c|}{ Area $3^{\text {d }}$} & \multicolumn{2}{|c|}{ Area $4^{e}$} & \multicolumn{2}{|c|}{ Area $5^{f}$} & \multicolumn{2}{|c|}{ Area $6^{g}$} & \multicolumn{2}{|c|}{ Area $8^{\text {h }}$} & \multicolumn{2}{|c|}{ Total } \\
\hline & & $N$ & $\%$ & $N$ & $\%$ & $N$ & $\%$ & $N$ & $\%$ & $N$ & $\%$ & $N$ & $\%$ & $N$ & $\%$ & $N$ & $\%$ \\
\hline MLDSD & $1,3,9,17, \mathrm{~B}, 10,14 \mathrm{a}, 39 / 41$ & 1 & 1 & 0 & 0 & 2 & 2.7 & 12 & 10.6 & 3 & 3.2 & 2 & 2.9 & 0 & 0 & 20 & 4 \\
\hline MLTSD & $1,3,9,3 \mathrm{ka}, 11,17,30, \mathrm{~B}, 10,14 \mathrm{a}, 39 / 41$ & 0 & 0 & 0 & 0 & 0 & 0 & 1 & 0.9 & 0 & 0 & 0 & 0 & 0 & 0 & 1 & 0.2 \\
\hline MMNSD & $1,3,9,26,3 \mathrm{ka}, 17, \mathrm{~B}, 10,14 \mathrm{a}, 39 / 41$ & 0 & 0 & 0 & 0 & 0 & 0 & 0 & 0 & 1 & 1.1 & 0 & 0 & 0 & 0 & 1 & 0.2 \\
\hline MMPSD & 1,3,9,26,3ka,17,30,B,10,14a,39/41 & 0 & 0 & 0 & 0 & 0 & 0 & 2 & 1.8 & 3 & 3.2 & 1 & 1.5 & 0 & 0 & 6 & 1.2 \\
\hline MRTSD & $\begin{array}{l}\text { 1,3,9,16,26,3ka, } 11,17,30, B, 10,14 \mathrm{a}, \\
39 / 41\end{array}$ & 0 & 0 & 1 & 63 & 0 & 0 & 0 & 0 & 0 & 0 & 0 & 0 & & O & & 02 \\
\hline NBBRG & $1,2 \mathrm{c}, \mathrm{B}, 10,18,28$ & 0 & 0 & 2 & 12.5 & 0 & 0 & 0 & 0 & 0 & 0 & 0 & 0 & 7 & 21.9 & $\begin{array}{l}1 \\
9\end{array}$ & $\begin{array}{l}0.2 \\
1.8\end{array}$ \\
\hline PBDGG & $1,2 \mathrm{c}, 3,17,10,28$ & 0 & 0 & 0 & 0 & 0 & 0 & 0 & 0 & 1 & 1.1 & 0 & 0 & 0 & 0 & 1 & 0.2 \\
\hline PBDQG & $1,2 \mathrm{c}, 3,17, \mathrm{~B}, 10,28$ & 0 & 0 & 0 & 0 & 0 & 0 & 1 & 0.9 & 1 & 1.1 & 0 & 0 & 0 & 0 & 2 & 0.4 \\
\hline PCLGG & $1,2 \mathrm{c}, 3,26,3 \mathrm{ka}, 10,28$ & 0 & 0 & 1 & 6.3 & 0 & 0 & 0 & 0 & 0 & 0 & 0 & 0 & 0 & 0 & 1 & 0.2 \\
\hline PCRKG & $1,2 \mathrm{c}, 3,26,3 \mathrm{ka}, 11,30,10,14 \mathrm{a}, 18,28$ & 0 & 0 & 1 & 6.3 & 0 & 0 & 0 & 0 & 0 & 0 & 0 & 0 & 0 & 0 & 1 & 0.2 \\
\hline TBBDG & $1,2 \mathrm{a}, 2 \mathrm{c}, 3,14 \mathrm{a}, 28$ & 0 & 0 & 0 & 0 & 0 & 0 & 0 & 0 & 1 & 1.1 & 0 & 0 & 0 & 0 & 1 & 0.2 \\
\hline TBBGJ & $1,2 \mathrm{a}, 2 \mathrm{c}, 3,10,28,39 / 41$ & 0 & 0 & 1 & 6.3 & 0 & 0 & 18 & 15.9 & 15 & 15.8 & 8 & 11.8 & 0 & 0 & 42 & 8.4 \\
\hline TBBGS & $1,2 \mathrm{a}, 2 \mathrm{c}, 3,10,21,28,39 / 41$ & 0 & 0 & 0 & 0 & 0 & 0 & 1 & 0.9 & 0 & 0 & 3 & 4.4 & 0 & 0 & 4 & 0.8 \\
\hline TBBJG & $1,2 \mathrm{a}, 2 \mathrm{c}, 3,10,14 \mathrm{a}, 28$ & 0 & 0 & 0 & 0 & 1 & 1.4 & 0 & 0 & 0 & 0 & 0 & 0 & 0 & 0 & 1 & 0.2 \\
\hline TBBJJ & $1,2 \mathrm{a}, 2 \mathrm{c}, 3,10,14 \mathrm{a}, 28,39 / 41$ & 0 & 0 & 0 & 0 & 0 & 0 & 0 & 0 & 0 & 0 & 2 & 2.9 & 0 & 0 & 2 & 0.4 \\
\hline TBBQJ & $1,2 \mathrm{a}, 2 \mathrm{c}, 3, \mathrm{~B}, 10,28,39 / 41$ & 0 & 0 & 0 & 0 & 0 & 0 & 1 & 0.9 & 1 & 1.1 & 0 & 0 & 0 & 0 & 2 & 0.4 \\
\hline TBJSB & $1,2 \mathrm{a}, 2 \mathrm{c}, 3,11,17, \mathrm{~B}, 10,14 \mathrm{a}$ & 1 & 1 & 0 & 0 & 0 & 0 & 0 & 0 & 0 & 0 & 0 & 0 & 0 & 0 & 1 & 0.2 \\
\hline TBRFG & $1,2 \mathrm{a}, 2 \mathrm{c}, 3,3 \mathrm{ka}, 11,30,14 \mathrm{a}, 18,28$ & 1 & 1 & 0 & 0 & 1 & 1.4 & 0 & 0 & 0 & 0 & 0 & 0 & 0 & 0 & 2 & 0.4 \\
\hline TBRKG & $1,2 \mathrm{a}, 2 \mathrm{c}, 3,3 \mathrm{ka}, 11,30,10,14 \mathrm{a}, 18,28$ & 11 & 10.7 & 0 & 0 & 12 & 16.2 & 1 & 0.9 & 6 & 6.3 & 0 & 0 & 1 & 3.1 & 31 & 6.2 \\
\hline TCGJG & $1,2 \mathrm{a}, 2 \mathrm{c}, 3,26,11,10,14 \mathrm{a}, 28$ & 1 & 1 & 0 & 0 & 0 & 0 & 0 & 0 & 0 & 0 & 0 & 0 & 0 & 0 & 1 & 0.2 \\
\hline TCRDG & $1,2 \mathrm{a}, 2 \mathrm{c}, 3,26,3 \mathrm{ka}, 11,30,14 \mathrm{a}, 28$ & 0 & 0 & 0 & 0 & 1 & 1.4 & 0 & 0 & 0 & 0 & 0 & 0 & 0 & 0 & 1 & 0.2 \\
\hline TCRFG & $1,2 \mathrm{a}, 2 \mathrm{c}, 3,26,3 \mathrm{ka}, 11,30,14 \mathrm{a}, 18,28$ & 2 & 1.9 & 0 & 0 & 2 & 2.7 & 0 & 0 & 1 & 1.1 & 0 & 0 & 0 & 0 & 5 & 1 \\
\hline TCRKG & $1,2 \mathrm{a}, 2 \mathrm{c}, 3,26,3 \mathrm{ka}, 11,30,10,14 \mathrm{a}, 18,28$ & 33 & 32 & 2 & 12.5 & 9 & 12.2 & 1 & 0.9 & 5 & 5.3 & 1 & 1.5 & 0 & 0 & 51 & 10.2 \\
\hline TCTDB & $1,2 \mathrm{a}, 2 \mathrm{c}, 3,26,3 \mathrm{ka}, 11,17,30,14 \mathrm{a}$ & 2 & 1.9 & 0 & 0 & 0 & 0 & 0 & 0 & 0 & 0 & 0 & 0 & 0 & 0 & 2 & 0.4 \\
\hline TCTNG & $1,2 \mathrm{a}, 2 \mathrm{c}, 3,26,3 \mathrm{ka}, 11,17,30, \mathrm{~B}, 14 \mathrm{a}, 28$ & 1 & 1 & 0 & 0 & 0 & 0 & 0 & 0 & 0 & 0 & 0 & 0 & 0 & 0 & 1 & 0.2 \\
\hline TDBGJ & $1,2 \mathrm{a}, 2 \mathrm{c}, 3,24,10,28,39 / 41$ & 0 & 0 & 0 & 0 & 0 & 0 & 1 & 0.9 & 0 & 0 & 0 & 0 & 0 & 0 & 1 & 0.2 \\
\hline TDBGQ & $1,2 \mathrm{a}, 2 \mathrm{c}, 3,24,10,21,28$ & 0 & 0 & 0 & 0 & 0 & 0 & 0 & 0 & 0 & 0 & 10 & 14.7 & 0 & 0 & 10 & 2 \\
\hline TDBJG & $1,2 \mathrm{a}, 2 \mathrm{c}, 3,24,10,14 \mathrm{a}, 28$ & 0 & 0 & 0 & 0 & 0 & 0 & 0 & 0 & 3 & 3.2 & 5 & 7.4 & 0 & 0 & 8 & 1.6 \\
\hline TDBJQ & $1,2 \mathrm{a}, 2 \mathrm{c}, 3,24,10,14 \mathrm{a}, 21,28$ & 0 & 0 & 0 & 0 & 0 & 0 & 0 & 0 & 0 & 0 & 1 & 1.5 & 0 & 0 & 1 & 0.2 \\
\hline TDGJG & $1,2 \mathrm{a}, 2 \mathrm{c}, 3,24,11,10,14 \mathrm{a}, 28$ & 2 & 1.9 & 0 & 0 & 0 & 0 & 1 & 0.9 & 0 & 0 & 0 & 0 & 0 & 0 & 3 & 0.6 \\
\hline TDPSB & $1,2 \mathrm{a}, 2 \mathrm{c}, 3,24,3 \mathrm{ka}, 17,30, \mathrm{~B}, 10,14 \mathrm{a}$ & 0 & 0 & 0 & 0 & 0 & 0 & 0 & 0 & 1 & 1.1 & 0 & 0 & 0 & 0 & 1 & 0.2 \\
\hline TFGJG & $1,2 \mathrm{a}, 2 \mathrm{c}, 3,24,26,11,10,14 \mathrm{a}, 28$ & 1 & 1 & 0 & 0 & 0 & 0 & 0 & 0 & 0 & 0 & 0 & 0 & 0 & 0 & 1 & 0.2 \\
\hline TFGJQ & $1,2 \mathrm{a}, 2 \mathrm{c}, 3,24,26,11,10,14 \mathrm{a}, 21,28$ & 0 & 0 & 0 & 0 & 0 & 0 & 0 & 0 & 0 & 0 & 1 & 1.5 & 0 & 0 & 1 & 0.2 \\
\hline TFPSB & $1,2 \mathrm{a}, 2 \mathrm{c}, 3,24,26,3 \mathrm{ka}, 17,30, \mathrm{~B}, 10,14 \mathrm{a}$ & 0 & 0 & 0 & 0 & 0 & 0 & 1 & 0.9 & 0 & 0 & 1 & 1.5 & 0 & 0 & 2 & 0.4 \\
\hline TGBGS & $1,2 \mathrm{a}, 2 \mathrm{c}, 3,16,10,21,28,39 / 41$ & 0 & 0 & 0 & 0 & 0 & 0 & 0 & 0 & 0 & 0 & 1 & 1.5 & 0 & 0 & 1 & 0.2 \\
\hline TNBGJ & $1,2 \mathrm{a}, 2 \mathrm{c}, 3,9,24,10,28,39 / 41$ & 0 & 0 & 0 & 0 & 1 & 1.4 & 26 & 23 & 21 & 22.1 & 7 & 10.3 & 0 & 0 & 55 & 11 \\
\hline TNBJJ & $1,2 \mathrm{a}, 2 \mathrm{c}, 3,9,24,10,14 \mathrm{a}, 28,39 / 41$ & 0 & 0 & 0 & 0 & 0 & 0 & 5 & 4.4 & 0 & 0 & 3 & 4.4 & 0 & 0 & 8 & 1.6 \\
\hline \multirow[t]{2}{*}{ TNRJJ } & $1,2 \mathrm{a}, 2 \mathrm{c}, 3,9,24,3 \mathrm{ka}, 11,30,10,14 \mathrm{a}, 28$ & & & & & & & & & & & & & & & & \\
\hline & $39 / 41$ & 0 & 0 & 0 & 0 & 1 & 1.4 & 0 & 0 & 1 & 1.1 & 4 & 5.9 & 0 & 0 & 6 & 1.2 \\
\hline TPBGD & $1,2 \mathrm{a}, 2 \mathrm{c}, 3,9,24,26,10,39 / 41$ & 0 & 0 & 0 & 0 & 0 & 0 & 1 & 0.9 & 0 & 0 & 0 & 0 & 0 & 0 & 1 & 0.2 \\
\hline TPBGJ & $1,2 \mathrm{a}, 2 \mathrm{c}, 3,9,24,26,10,28,39 / 41$ & 0 & 0 & 0 & 0 & 0 & 0 & 4 & 3.5 & 2 & 2.1 & 1 & 1.5 & 0 & 0 & 7 & 1.4 \\
\hline TPBQJ & $1,2 \mathrm{a}, 2 \mathrm{c}, 3,9,24,26, \mathrm{~B}, 10,28,39 / 41$ & 0 & 0 & 0 & 0 & 0 & 0 & 1 & 0.9 & 0 & 0 & 0 & 0 & 0 & 0 & 1 & 0.2 \\
\hline Total & $\ldots$ & 103 & $\ldots$ & 16 & $\ldots$ & 74 & $\ldots$ & 113 & $\ldots$ & 95 & $\ldots$ & 68 & $\ldots$ & 32 & $\ldots$ & 501 & $\ldots$ \\
\hline
\end{tabular}


in 2012. A modified version of Nei's genetic distance (22) between isolates in areas 1, 2, 3, 4, 5, 6, and 8 was calculated with NTSYSpc v2.1 (Exeter Software), in which the frequency of isolates with virulence to a leaf rust resistance gene was used in place of allele frequency. The distance matrix of Nei's virulence distance between the areas was plotted with unweighted pair group method with arithmetic means clustering in NTSYS-pc v2.1.

The leaf rust resistance genes present in the current soft red winter wheat cultivars, hard red winter wheat cultivars, and hard red spring wheat cultivars were postulated based on ITs to different virulence phenotypes of $P$. triticina using previously cited methods $(9,23)$. The ITs of the cultivars to different $P$. triticina isolates and the postulated leaf rust resistance genotypes of the cultivars are available at the USDA-ARS Cereal Disease Laboratory website in the germplasm evaluation section.

\section{Results}

Leaf rust occurrence and isolate collections. Wheat leaf rust was widespread in the Great Plains, Ohio Valley, and the southeastern and eastern states in 2012. Leaf rust was present in Louisiana in early February and in early March in Texas. By the end of July, leaf rust was present in North Dakota and Minnesota. The states with the highest leaf rust severity levels in wheat fields included parts of Texas, Kansas, Nebraska, Arkansas, eastern North Carolina, Maryland, and Virginia. Leaf rust was particularly severe in North Carolina, causing an estimated 5\% yield loss statewide. Because most of the leading wheat cultivars are susceptible to leaf rust, many wheat fields in the southeastern states, southern and northern Great Plains regions, and Ohio Valley were sprayed with fungicide to prevent yield losses. A complete summary of the wheat leaf rust incidence and severity in 2012 in the United States can be found at the USDA-ARS Cereal Disease Laboratory website (https://www.ars.usda.gov/SP2UserFiles/ad_hoc/36400500 Cerealrustbulletins/12CRB9\%20fin.pdf). Samples of leaf rust were obtained from 23 states in areas 1,2, 3, 4, 5, 6, and 8 from a total of 259 collections.

Distribution of virulence phenotypes. In 2012, 74 virulence phenotypes of wheat leaf rust were identified in the United States from 501 single-uredinial isolates that were tested on the Thatcher lines (Table 1). Phenotypes TNBGJ (11\%), TCRKG $(10.2 \%)$, and MBTNB (9.8\%) were the three most frequent phenotypes across the United States. TNBGJ was found in the Great Plains in areas 4, 5 , and 6 and one isolate was found in area 3. TCRKG was found in all areas except for area 8; MBTNB was found in all areas except areas 6 and 8. No virulence phenotype was found in all areas. In the southeastern states (area 1), 19 virulence phenotypes were found among the 103 isolates that were tested (Table 1). Phenotypes TCRKG (32\%), MBTNB (18.4\%), and MCTNB (13.6\%) were the three most common phenotypes in this area. In the northeastern states (area 2), 11 phenotypes were described among the 16 isolates that were tested. Two isolates were found for five phenotypes (LCDNB, MCGJG, MCTNB, NBBRG, and TCRKG) in this area. In the Ohio Valley states (area 3), 23 phenotypes were found among the 74 isolates that were tested. Phenotypes MBTNB (33.8\%), TBRKG (16.2\%), and TCRKG (12.2\%) were the three most common phenotypes in this area. In Texas and Oklahoma (area 4), 29 phenotypes were found among the 113 isolates tested. Phenotypes TNBGJ (23\%), TBBGJ (15.9\%), and MLDSD (10.6\%) were the three most common phenotypes in this area. In Kansas and Nebraska (area 5), 26 virulence phenotypes were found among the 95 isolates tested. Phenotypes TNBGJ (22.1\%), TBBGJ (15.8\%), and MBDSD (10.5\%) were the three most common phenotypes in this area. In South Dakota, North Dakota, and Minnesota (area 6), 23 phenotypes were found among the 68 isolates tested. Phenotypes TDBGQ (14.7\%), TBBGJ (11.8\%), and TNBGJ $(10.3 \%)$ were the three most common phenotypes in this area. In Idaho and Washington state (area 8), 14 phenotypes were found among the 32 isolates that were tested. MBBJG (21.9\%) and NBBRG (21.9\%) were two most common phenotypes in this region.

Virulence frequencies. Frequencies of virulence to the $L r$ genes differed among the regional populations of $P$. triticina in the United States and are listed in Table 2. Virulence to Lrl6 was found at very low levels in areas 2, 3, 4, and 6. Virulence to $L r 21$ was found only in areas 4 and 6 . No isolates with virulence to $L r 42$ were found. Virulence to the other $\operatorname{Lr}$ genes was found at variable

Table 2. Number and frequency (\%) of isolates of Puccinia triticina in the United States in 2012 virulent to 20 lines of wheat with single genes for leaf rust resistance

\begin{tabular}{|c|c|c|c|c|c|c|c|c|c|c|c|c|c|c|c|c|}
\hline \multirow[b]{2}{*}{ Gene } & \multicolumn{2}{|c|}{ Area $1^{a}$} & \multicolumn{2}{|c|}{ Area $2^{b}$} & \multicolumn{2}{|c|}{ Area $3^{c}$} & \multicolumn{2}{|c|}{ Area $4^{d}$} & \multicolumn{2}{|c|}{ Area $5^{\mathrm{e}}$} & \multicolumn{2}{|c|}{ Area $6^{f}$} & \multicolumn{2}{|c|}{ Area $8^{g}$} & \multicolumn{2}{|c|}{ Total } \\
\hline & $N$ & $\%$ & $N$ & $\%$ & $N$ & $\%$ & $N$ & $\%$ & $N$ & $\%$ & $N$ & $\%$ & $N$ & $\%$ & $N$ & $\%$ \\
\hline Lrl & 103 & 100 & 16 & 100 & 73 & 98.6 & 113 & 100 & 95 & 100 & 68 & 100 & 32 & 100 & 500 & 99.8 \\
\hline$L r 2 a$ & 55 & 53.4 & 3 & 18.8 & 28 & 37.8 & 62 & 54.9 & 57 & 60 & 48 & 70.6 & 1 & 3.1 & 254 & 50.7 \\
\hline$L r 2 c$ & 55 & 53.4 & 7 & 43.8 & 29 & 39.2 & 63 & 55.8 & 59 & 62.1 & 48 & 70.6 & 8 & 25 & 269 & 53.7 \\
\hline Lr3 & 103 & 100 & 12 & 75 & 74 & 100 & 113 & 100 & 95 & 100 & 68 & 100 & 25 & 78.1 & 490 & 97.8 \\
\hline $\operatorname{Lr} 9$ & 1 & 1 & 1 & 6.3 & 4 & 5.4 & 52 & 46 & 31 & 32.6 & 18 & 26.5 & 0 & 0 & 107 & 21.4 \\
\hline Lr16 & 0 & 0 & 1 & 6.3 & 2 & 2.7 & 2 & 1.8 & 0 & 0 & 1 & 1.5 & 0 & 0 & 6 & 1.2 \\
\hline Lr24 & 10 & 9.7 & 0 & 0 & 9 & 12.2 & 61 & 54 & 39 & 41.1 & 37 & 54.4 & 1 & 3.1 & 157 & 31.3 \\
\hline $\operatorname{Lr} 26$ & 68 & 66 & 12 & 75 & 27 & 36.5 & 32 & 28.3 & 23 & 24.2 & 10 & 14.7 & 10 & 31.3 & 182 & 36.3 \\
\hline Lr3ka & 94 & 91.3 & 9 & 56.3 & 64 & 86.5 & 18 & 15.9 & 34 & 35.8 & 17 & 25 & 4 & 12.5 & 240 & 47.9 \\
\hline Lrl1 & 98 & 95.1 & 10 & 62.5 & 58 & 78.4 & 5 & 4.4 & 19 & 20 & 8 & 11.8 & 3 & 9.4 & 201 & 40.1 \\
\hline Lr17 & 47 & 45.6 & 6 & 37.5 & 44 & 59.5 & 51 & 45.1 & 39 & 41.1 & 21 & 30.9 & 10 & 31.3 & 218 & 43.5 \\
\hline Lr30 & 92 & 89.3 & 7 & 43.8 & 62 & 83.8 & 10 & 8.8 & 32 & 33.7 & 17 & 25 & 1 & 3.1 & 221 & 44.1 \\
\hline $\operatorname{LrB}$ & 45 & 43.7 & 8 & 50 & 45 & 60.8 & 54 & 47.8 & 39 & 41.1 & 21 & 30.9 & 19 & 59.4 & 231 & 46.1 \\
\hline Lr10 & 64 & 62.1 & 11 & 68.8 & 41 & 55.4 & 112 & 99.1 & 87 & 91.6 & 66 & 97.1 & 32 & 100 & 413 & 82.4 \\
\hline Lr14a & 100 & 97.1 & 11 & 68.8 & 73 & 98.6 & 59 & 52.2 & 54 & 56.8 & 38 & 55.9 & 24 & 75 & 359 & 71.7 \\
\hline Lr18 & 47 & 45.6 & 6 & 37.5 & 24 & 32.4 & 2 & 1.8 & 12 & 12.6 & 1 & 1.5 & 9 & 28.1 & 101 & 20.2 \\
\hline $\operatorname{Lr} 21$ & 0 & 0 & 0 & 0 & 0 & 0 & 1 & 0.9 & 0 & 0 & 16 & 23.5 & 0 & 0 & 17 & 3.4 \\
\hline $\operatorname{Lr} 28$ & 57 & 55.3 & 10 & 62.5 & 29 & 39.2 & 61 & 54 & 58 & 61.1 & 48 & 70.6 & 23 & 71.9 & 286 & 57.1 \\
\hline Lr39/41 & 1 & 1 & 2 & 12.5 & 5 & 6.8 & 82 & 72.6 & 57 & 60 & 38 & 55.9 & 0 & 0 & 185 & 36.9 \\
\hline Lr42 & 0 & 0 & 0 & 0 & 0 & 0 & 0 & 0.0 & 0 & 0 & 0 & 0 & 0 & 0 & 0 & 0.0 \\
\hline Total & 103 & $\ldots$ & 16 & $\ldots$ & 74 & $\ldots$ & 113 & $\ldots$ & 95 & $\ldots$ & 68 & $\ldots$ & 32 & $\ldots$ & 501 & $\ldots$ \\
\hline
\end{tabular}

${ }^{a}$ States of Alabama, Arkansas, Georgia, Louisiana, Mississippi, North Carolina, and Virginia.

${ }^{\mathrm{b}}$ State of New York.

c States of Illinois, Indiana, eastern Missouri, Ohio, and Wisconsin.

${ }^{\mathrm{d}}$ States of Oklahoma and Texas.

e States of Kansas, western Missouri, and Nebraska.

${ }^{\mathrm{f}}$ States of Minnesota, North Dakota, and South Dakota.

g States of Montana, Washington, and Idaho. 
levels across the different regions. Based on frequencies of virulence to $L r$ genes, the areas split into three groups using Nei's genetic distance adapted for virulence (Fig. 2). Isolates in areas 1, 2, and 3 were separated from isolates in areas 4, 5, and 6 by 0.21 Nei's distance. Isolates within each of these two groups were more closely related for virulence, with smaller virulence distances between areas. Isolates in area 8 were the most distinct for virulence compared with isolates in the other two groups.

In area 1 (Fig. 3A), the frequency of isolates with virulence to $\operatorname{Lr} 9$ and $L r 24$ declined from 2011 and frequency of isolates with virulence to $\mathrm{Lrll}$ and $\mathrm{Lrl} 8$ increased. Frequency of isolates with virulence to $L r 26$ remained nearly unchanged. In area 4 (Fig. $3 \mathrm{~B})$, the frequency of isolates with virulence to $\operatorname{Lr} 9$ increased slightly compared with 2011 , while virulence to $L r 26$ declined slightly. Virulence to $\mathrm{Lr} 24$ and $\mathrm{Lr} 17$ remained nearly unchanged. In 2012, virulence to $L r 39 / 41$ in area 4 was at $72.6 \%$ (Table 2) compared with $59.7 \%$ in 2011 and $49.6 \%$ in 2010. In area 6 (Fig. $3 \mathrm{C}$ ), the frequency of isolates with virulence to $\operatorname{Lr} 2 a$ increased slightly, while virulence to $\operatorname{Lr} 24$ and $\operatorname{Lr} 17$ decreased. Virulence to $\operatorname{Lrl6}$ remained relatively unchanged. In 2012, virulence to Lr21 in area 6 was $23.5 \%$ compared with $17.6 \%$ in 2011 and $8.1 \%$ in 2010 .

\section{Discussion}

In 2012, as in previous years, the leaf rust resistance genes that are present in the hard red winter and soft red winter wheat cultivars likely selected the most prevalent virulence phenotypes of $P$. triticina. The most common phenotype, TNBGJ, is virulent to Lr39/41 that is present in many hard red winter wheat cultivars such as 'Armour', 'Fuller', 'TAM 112', 'Postrock', and Overley that were widely grown in the southern Great Plains in 2012 (26). The second most common phenotype, TCRKG, is virulent to $\operatorname{Lr} 2 a$, $L r 11, L r 18$, and $L r 26$ and is virulent to widely grown soft red winter wheat cultivars such as 'Shirley' (postulated to have $L r 2 a, \operatorname{Lr} 11$, and Lr26) 'Jamestown' (Lr11 and Lr18), 'USG 3555' (Lr26), 'SS205' (Lr11 and Lr26), 'Pioneer 26R15' (Lr11), 'Pioneer 26R22' (Lr11), 'Coker 9553' (Lr11) 'Progeny 166' (Lrl) 'Branson' (Lr2a and Lr10), and 'Progeny 185' (Lr10) (J. Kolmer, unpublished data). The third most common phenotype, MBTNB, is virulent to soft red winter wheat cultivars that have genes $\mathrm{Lrl}$ and $\mathrm{Lrll}$. In 2011 (13), the three most common virulence phenotypes in the United States were TBBGJ, with virulence to Lr39/41; MLDSD, with virulence to $L r 17$, and $L r 39 / L r 41$, and TCRKG.

There were strong geographical differences in distribution of the P. triticina phenotypes. Phenotypes TCRKG, MBTNB, MCTNB (virulent to $L r 11$ and $L r 26$ ), and TBRKG (virulent to $L r 2 a$ and Lr11) were the most common phenotypes in the soft red winter wheat areas 1,2, and 3, where soft red winter wheat cultivars with genes $L r 11, L r 18$, and $L r 26$ are grown. In the hard red wheat region of areas 4, 5 and 6, phenotypes TNBGJ, TBBGJ (virulent to

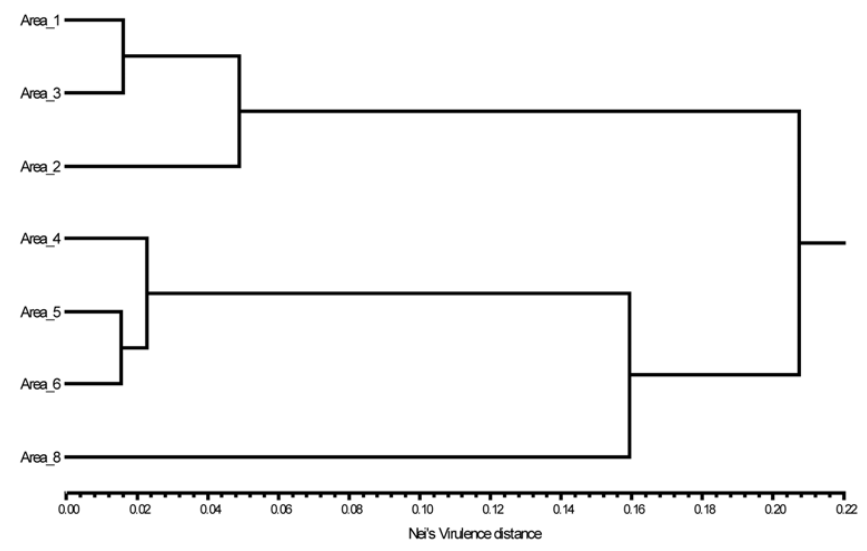

Fig. 2. Unweighted pair group method with arithmetic means dendrogram of Nei's genetic distance adapted for virulence of Puccinia triticina isolates in areas 1, 2, 3, 4, 5, and 6 in the United States in 2012.
Lr39/41), MLDSD (virulent to Lr17 and Lr39/41), and MBDSD (virulent to $L r 17$ and $L r 39 / 41$ ) were the most common phenotypes. These phenotypes were likely selected by hard red winter wheat cultivars with genes $\operatorname{Lrl} 7$ and $\operatorname{Lr39} / 41$. In the spring region of area 6, TDBGQ, with virulence to $L r 2 a$ and $L r 21$, was the most common phenotype, having likely been selected by hard red spring wheat cultivars with $L r 21$. In area 8 (Washington state and Idaho), phenotype MBBJG and MCBJG were common phenotypes yet were not found in any other area. Phenotype NBBRG was found in areas 2 and 8 but not in other areas. The geographic differences in phenotype distributions are also seen in the Nei's virulence distance between isolates in the different areas. Isolates from the soft red winter wheat region of the southeastern states, Ohio Valley, and northeastern states were more similar for virulence compared with isolates from areas 4, 5, and 6 of the Great Plains, where hard red winter wheat and hard red spring wheat cultivars are grown. Isolates in area 8, where soft white winter and spring wheats are grown, were distinct compared with isolates in the other two groups.

In 2012, virulence to $L r 39 / 41$ continued to increase in areas 4, 5, and 6, likely due to the presence of this gene in many hard red winter wheat cultivars. Virulence to Lr39/41 and the number of
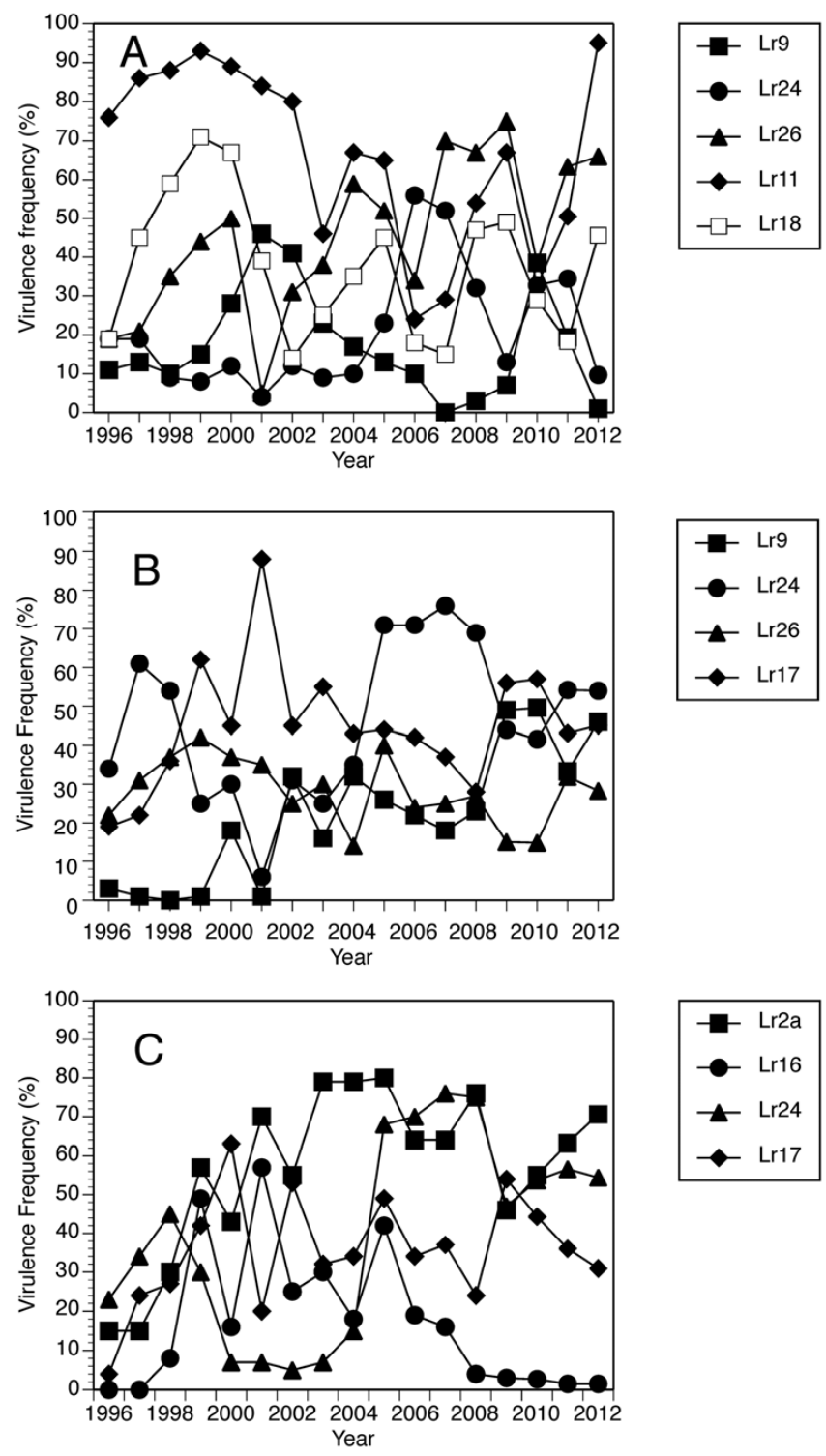

Fig. 3. Frequency (\%) of Puccinia triticina isolates with virulence to selected leaf rust resistance genes from 1996 to 2012 in the following areas of the United States: A, southeastern states (area 1); B, southern Great Plains (area 4); and C, northern Great Plains (area 6). 
phenotypes with virulence to this gene has increased since 2010 (12), when phenotypes with virulence to $L r 39 / 41$ but not to $L r 9$ were first found in high frequencies. Prior to 2010, almost all isolates that were virulent to $\operatorname{Lr39/41}$ were also virulent to $\operatorname{Lr} 9$. Phenotype TBBGS, detected in areas 4 and 6 for the first time in 2012, is the first phenotype to combine virulence to $\operatorname{Lr} 21$ and $\operatorname{Lr39} / 41$. Because these genes are present in hard red spring wheat and hard red winter wheat cultivars, respectively, this phenotype is widely adapted to the wheat cultivars grown in the Great Plains region and may increase in future years.

The widespread use of wheat cultivars in the United States with genes that are effective in seedling plants and condition resistance to specific leaf rust phenotypes has led to the development of a $P$. triticina population that is highly diverse for virulence. Because populations of $P$. triticina in the United States are extremely large, it would be expected that recurrent mutations would generate new virulence phenotypes that will increase in response to leaf rust resistance genes in wheat cultivars. As new leaf-rust-resistant cultivars are released, it will be important to characterize the resistance in these cultivars by gene postulation, molecular markers, or genetic analysis to order to determine whether leaf rust resistance genes in host cultivars have selected for new $P$. triticina virulence phenotypes.

\section{Literature Cited}

1. Appel, J. A., DeWolf, E., Bockus, W. W., and Todd, T. 2012. Preliminary 2012 Kansas wheat disease loss estimates. Kans. Coop. Plant Dis. Surv. Rep. Kans. Dep. Agric. http://agriculture.ks.gov/docs/default-source/pp-disease-reports-2012/2012-ks-wheat-disease-loss-estimates.pdf?sfvrsn=3

2. German, S. E., Barcellos, A., Chaves, M., Kohli, M., Campos, P., and de Viedma, L. 2007. The situation of common wheat rusts in the Southern Cone of America and perspectives for control. Aust. J. Agric. Res. 58:620-630.

3. Johnston, C. O. 1931. Effect of leaf rust infection on yield of certain varieties of wheat. J. Am. Soc. Agron. 23:1-12.

4. Johnston, C. O., Caldwell, R. M., Compton, L. E., and Browder, L. E. 1968. Physiologic races of Puccinia recondita f. sp. tritici in the United States from 1926 through 1960. U. S. Dep. Agric. Tech. Bull. 1393:1-18.

5. Kolmer, J., Chen, X., and Jin, Y. 2009. Diseases which challenge global wheat production - the wheat rusts. Pages 89-124 in: Wheat: Science and Trade. B. F. Carver, ed. Wiley-Blackwell, Ames, IA.

6. Kolmer, J., and Anderson, J. A. 2011. First detection in North America of virulence in wheat leaf rust (Puccinia triticina) to seedling plants of wheat with $\operatorname{Lr21}$. Plant Dis. 95:1032.

7. Kolmer, J. A. 1999. Physiologic specialization of Puccinia triticina in Canada in 1997. Plant Dis. 83:194-197.

8. Kolmer, J. A. 1999. Virulence dynamics, phenotypic diversity, and virulence complexity in two populations of Puccinia triticina in Canada from 19871997. Can. J. Bot. 77:333-338.

9. Kolmer, J. A. 2003. Postulation of leaf rust resistance genes in selected soft red winter wheats. Crop Sci. 43:1266-1274.

10. Kolmer, J. A., Long, D. L., and Hughes, M. E. 2008. Physiologic specialization of Puccinia triticina on wheat in the United States in 2006. Plant Dis. 92:1241-1246.

11. Kolmer, J. A., Long, D. L., and Hughes, M. E. 2009. Physiologic specialization of Puccinia triticina on wheat in the United States in 2007. Plant Dis. 93:538-544.

12. Kolmer, J. A., Long, D. L., and Hughes, M. E. 2012. Physiologic specialization of Puccinia triticina on wheat in the United States in 2010. Plant Dis. 96:1216-1221.

13. Kolmer, J. A., and Hughes, M. E. 2013. Physiological specialization of Puccinia triticina on wheat in the United States in 2011. Plant Dis. 97:1103-1108.

14. Kolmer, J. A., Mert, Z., Akan, K., Demir, L., Unsal, R., Sermet, C., Keser, M., Akin, B., and Morgounov, A. 2013. Virulence of Puccinia triticina in Turkey and leaf rust resistance in Turkish wheat cultivars. Eur. J. Plant Pathol. 135:703-716.

15. Leonard, K. J., Roelfs, A. P., and Long, D. L. 1992. Diversity of virulence within and among populations of Puccinia recondita f. sp. tritici in different areas of the United States. Plant Dis. 76:500-504.

16. Long, D. L., and Kolmer, J. A. 1989. A North American system of nomenclature for Puccinia recondita f. sp. tritici. Phytopathology 79:525-529.

17. Long, D. L., Schafer, J. F., and Roelfs, A. P. 1985. Specific virulence of Puccinia recondita f. sp. tritici in the United States from 1978 through 1983. Plant Dis. 69:343-347.

18. Mains, E. B., and Jackson, H. S. 1926. Physiologic specialization in the leaf rust of wheat, Puccinia triticina. Phytopathology 16:89-120.

19. McCallum, B. D., and Seto-Goh, P. 2006. Physiological specialization of Puccinia triticina, the casual agent of wheat leaf rust, in Canada in 2004. Can. J. Plant Pathol. 28:566-576.

20. Morgounov, A., Ablova, L., Babayants, O., Babayants, L., Bespalova, L., Khudormov, Z., Litvinenko, N., Shamanin, V., and Syukov, V. 2011. Genetic protection of wheat rusts and development of resistant varieties in Russia and Ukraine. Euphytica 179:297-311.

21. Morgounov, A., Rosseeva, L., and Koyshibayev, M. 2007. Leaf rust of spring wheat in Northern Kazakhstan and Siberia: incidence, virulence, and breeding for resistance. Aust. J. Agric. Res. 58:847-853.

22. Nei, M. 1972. Genetic distance between populations. Am. Nat. 106:283292.

23. Oelke, L. M., and Kolmer, J. A. 2004. Characterization of leaf rust resistance in hard red spring wheat cultivars. Plant Dis. 88:1127-1133.

24. Roelfs, A. P. 1989. Epidemiology of the cereal rusts in North America. Can. J. Plant Pathol. 11:86-90.

25. Roelfs, A. P., Singh, R. P., and Saari, E. E. 1992. Rust Diseases of Wheat: Concepts and Methods of Disease Management. CIMMYT, Mexico, D.F.

26. Watson, S. 2012. Wheat Varieties For Kansas and the Great Plains 2013. Lone Tree Publishing, Topeka, KS. 